\title{
The Scope of Discretion in Government Administration Law: Constitutional or Unconstitutional?
}

\author{
Victor Imanuel W. Nalle
}

Faculty of Law, Darma Cendika Catholic University, Indonesia. E-mail: vicnalle@yahoo.com

\begin{tabular}{l} 
ARTICLE INFO \\
\hline Keywords: \\
Constitutionality; \\
Discretion; Policy Rule; \\
Rule of Law \\
How to cite: \\
Nalle, V.I.W. (2018). The \\
Scope of Discretion in \\
Government \\
Administration Law: \\
Constitutional or \\
Unconstitutional? \\
Hasanuddin Law Review, \\
4(1): 1-14. \\
DOI: \\
10.20956/halrev.v4i1.1316
\end{tabular}

\begin{abstract}
Law No. 30 of 2014 on Government Administration (Government Administration Law) has set the scope of discretion in Indonesian legal system. But the form of discretion is limited in scope government decision (KTUN) and factual actions of the government. The restriction implicates circulars or others policy rule is not a form of discretion. In addition, the provisions concerning the terms of use discretion, procedures and legal effect of discretion in the Government Administration Law are not applicable to the use of policy rule. In fact, the substance of discretion in policy rule (e.g. circulars and instructions) has the potential of conflicting laws and regulations and/or General Principles of Good Administration. The legal issues in this study are the constitutionality of the scope of discretion in Article 1 point 9 and Article 23 paragraph (1) of the Government Administration Law. This analysis showed that limits the scope of discretion in Government Administration Law contrary to formal elements, substantive, and control mechanisms within the rule of law. This analysis also suggests the expansion of the scope of discretion in the Government Administration Law and setting policy rules as the object of the petition for judicial review so that there is a control mechanism by trial to discretion in the form of policy rule.
\end{abstract}

Copyright (C) 2018 HALREV. All rights reserved.

\section{Introduction}

Public administration in Indonesia for decades runs without law which regulates it comprehensively. This condition is different from other countries, such as the United States and the Netherlands. The United States has the Administrative Procedure Act (APA) while the Dutch have the Algemene Wet Bestuursrecht (AWB). Indonesia finally had a law on public administration when the government enacted Law Number 30 Year 2014 on Government Administration (Government Administration Law).

One chapter of the Government Administration Law regulates discretion (Chapter VI). Prior to the existence of the Government Administration Law, the concept of discretion can only be traced in the legal literature of state administration. Scholars regard 
discretion as a central and inevitable concept for understanding the embodiment of the rule of law. Discretion is placed in the context of the freedom of government organizations in solving government problems. ${ }^{1}$ The existence of the Government Administration Law then regulates the discretion related to the requirements, procedures, and legal consequences.

Discretion in Article 1 Number 9 is defined as decisions and/or acts established and/or executed by Government Officials to address concrete issues faced in the administration of the government in the case of legislation that provides unorganized, incomplete or unclear options, and/or the stagnation of government. Based on the provisions of Article 1 Number 9 above, the discretion has 2 (two) forms, namely decision and/or action. The decision referred to in these provisions is Government Administrative Decisions which are also called State Administrative Decisions (KTUN). The action referred to the Government Administration Law is the act of a Government Official or other state organizer to perform and/or not perform factual actions in the context of the administration of government (factual act of government).

The restrictions on the form of discretion in Article 1 Number 9 imply the law not regulates circulars or other form of policy rule as the scope of discretion. Whereas the policy rule is one form of discretion that does not included as KTUN or Government Administrative Act. Other implications, the provisions on discretionary requirements, procedures, and legal consequences of discretion in the Government Administration Law may be deemed not to be applicable in the use of policy rules as instruments of public administration. Whereas the substance of policy rule (e.g. circulars and instructions) in discretion may not be in accordance with General Principles of Good Administration (AUPB) or conflict of interest.

Therefore, this article explores the following questions; whether the scope of discretion in Government Administration Law is unconstitutional when analysed by rule of law principle in constitution, and if so, what should the government administration law say to be compatible with rule of law?

\section{The Concept of Discretion}

The concept of discretion cannot be separated from its Latin root, 'discernere'. Discernere in English paired with discernment terminology which means wisdom. ${ }^{2}$ The etymological significance shows the importance of wisdom for government officials when implementing discretion. Darumurti, ${ }^{3}$ defines discretion as an individual decision or action of government based on the government's power to be free to make choices. Government in the context of discretion is given the choice to act or not to act for the sake of public good. The freedom to choose is prescribed in legislation or even is not prescribed from legislation.

Another more elaborative definition is delivered by Koch Jr. as quoted by L.E. Sitorus. Based on Koch Jr. there are 3 (three) scopes of discretion that need to be understood. First, discretion as the authority to make individualizing discretion by decisions those are individual in the application of the rules. Second is discretion as freedom to fill the

1 Li, L. (2014). Judicial Discretion within Adjudicative Committee Proceedings in China: a Bounded Rationality Analysis. Berlin: Springer-Verlag, p.12.

2 Fletcher, G.P. (1984). "Some Unwise Reflections about Discretion", Law and Contemporary Problem, 47(4): 269-286.

3 Darumurti, K.D. (2016). Diskresi: Kajian Teori Hukum, Yogyakarta: Genta Publishing, p. 28. 
vacuum in the delegate's authority with the aim of carrying out a determined administrative function (executing discretion). Third is discretion as the power to take action in the framework of a common goal (policy making discretion). ${ }^{4}$ Darumurti then elaborates two factors that related with discretion:

a. The government must act on the principle of legality but also need to be flexible under certain conditions. Governments in certain circumstances cannot avoid the nature of the interpretive law. Although legal norms have been formulated strictly but it must be interpreted when faced with the context of the implementation. ${ }^{5}$

The interpretive nature of law is caused by a simple premise. According to H.L.A. Hart, the lawmaker will never know what's going on in the future. The lawmakers will try to regulate the problems that arise today, but cannot predict exactly what will happen in the future. Hart called the limitations of this lawmaker as a relative ignorance of fact. There is also a relative indeterminacy of aim when the legislator in general has determined the goal of the law. However, the law at the level of implementation will compete with many interests that must be compromised. ${ }^{6}$ Hart's limitations show the urgency of discretion. If the government does not take the path of discretion then there is the risk of stagnation of government. Therefore, the government should be flexible but still pay attention to the goals set by the legislator.

An example of the limitations of legislation relating to relative indeterminacy of aim can be seen in the context of the implementation of Surabaya City Local Regulation No. 8 of 2014 on the Arrangement of Supermarkets in Surabaya (Perda No. 8 Year 2014). The regulation regulates the maximum hours of mini market service. The initial spirit of this provision is to protect traditional markets or stores. The protection is expected to improve the economy of small communities through traditional shops or markets. However, the initial objective becomes relative when faced with situations of potential job losses for workers in minimarket trading services. This context can actually be legitimacy for the discretion that government officials need to take in implementing the law.

b. The second factor is the exception situation associated with the functional nature of the discretion. Implementation of governmental power has the exception situation of the law for reasons of urgent need or emergency. The government should not be passive in the face of such urgent or emergency situations. Government should be active by taking steps other than those set out in the legislation.

If discretion is functional, then the form and nomenclature of the discretion should also be seen from its function. Therefore, the limitation of the form of discretionary usage becomes contradictory to the functional nature. However, the limitation of discretionary functionality is precisely regulated in the definition of discretion in the Government Administration Law.

\footnotetext{
Sitorus, L.E. (2016). “Kebijakan Bailout Century: Diskresi atau Kriminalisasi Kebijakan”, Jurnal Hukum E Pembangunan, 46(1): 22-49.

5 Darumurti, Op.cit, pp. 29-32.

6 Hart, H.L.A. (2013). “Discretion”. Harvard Law Review, 127(2): 661-663.
} 
Both discretionary driving factors indicate the paradigm of utilitarianism in the exercise of government authority. If the law on which the authority is based can be interpreted differently to achieve the goals of the government, then the government can exercise discretion. Thus, the implementation of the law is solely seen as an effort to achieve the objectives of the law. The meaning of the text of the law is dynamic in the dimensions of cognition and implementation as long as it is on track to achieve that goal.

The paradigm of utilitarianism in the law can be interpreted as the value of purposiveness of the law. The value of purposiveness, according to Gustav Radbruch, is actually under justice and legal certainty. The purposiveness of the law is in the last place, while the value of justice is the main goal.

In ranking these values, we assign to last place the purposiveness of the law in serving the public benefit. By no means is law anything and everything that 'benefits the people'. Rather, what benefits the people is, in the long run, only that which law is, namely, that which creates legal certainty and strives toward justice. Legal certainty (which is characteristic of every positive-law statute simply in virtue of the statute's having been enacted) takes a curious middle place between the other two values, purposiveness and justice, because it is required not only for the public benefit but also for justice. ${ }^{7}$

Aspects of purposiveness of discretion can also be seen in discretionary settings in the Government Administration Law. Under Article 22 Paragraph (2) Sub-Paragraph d of the Government Administration Law, any use of Government Officials' Discretion aims to overcome the stagnation of government in certain circumstances for the benefit and the public interest. However, as Radbruch argues, the aspect of purposiveness must be balanced with justice and certainty aspects. The advantages of the modern legal system exist in the guarantee of legal certainty. Therefore, setting of the discretion functionality should not be arbitrary by ignoring the legal certainty.

Therefore, the next discussion will present some examples of discretion that ignore the legal certainty aspect. Government officials in practice tend to use the nomenclature of a circular in the exercise of discretion. This condition is certainly different from the direction in the Government Administration Law which regulates the use of discretion with the nomenclature of KTUN and factual actions.

\section{Implementation of Discretion in Indonesia}

As explained in the previous discussion, the nomenclature that can be used in the use of discretion is the KTUN and the factual actions of the government. If we refer to the definition of KTUN in the Government Administration Law which extends the definition of KTUN in Law No. 5 of 1986 on Administrative Court (Administrative Court Law), it can be concluded that the use of KTUN as an instrument of discretion is contrary to the nature of discretion. Article 87 of the Government Administration Law provides that the KTUN in the Administrative Court Law must be interpreted as:

7 Radbruch, G. (2006). "Statutory Lawlessness and Supra-Statutory Law (1946)," Oxford Journal of Legal Studies, 26(1), 1-11. DOI: http://dx.doi.org/10.1093/ojls/ gqi041. 
a. A written determination which also includes factual acts;

b. Decisions of the board and/or state administration officials in the executive, legislative, judicial, and other state administrations;

c. The KTUN shall be subject to the provisions of the law and the general principles of good administration (AUPB);

d. The KTUN is final in a broader sense;

e. The KTUN has potential legal impacts; and/or

f. The KTUN applies to the citizens.

The provision gives the meaning of KTUN as a written stipulation based on the law and AUPB. In addition, Article 1 Sub-Article 9 of the Government Administration Law regulates discretion to be used when the substance of legislation provides choice, does not regulate, incomplete or unclear, and/or government stagnation. This means that KTUN can be used to implement the provisions of the laws and regulations, the AUPB principles, the existence of the options granted by law or the existence of substance which is unclear in the legislation.

One feature of choice in legislation aimed at government officials is the use of the word "can" in the formulation of norms. These characteristics have been affirmed in the Attachment of Law Number 12 Year 2011 on the Formation of Laws (Law-Making Law). The delegation of authority to government officials to form the KTUN is marked by the formulation of the authority norm "determined by". This feature is based on general provisions in the Administrative Court Law and Government Administration Law which classify the KTUN as a determination or written provision. Therefore, if there is a choice or option for a government official to form or not to form a KTUN then it should be phrased by the "can be determined by".

The research conducted by Permana, ${ }^{8}$ analyzed the sample of KTUN that was determined because of bound discretion. Permana analyzed the Decision of the Regent of Klaten Number 888/01/12/09Rhs which dismissed with disrespect one of Civil Servant. The Decision is based on the provisions of Article 8 letter $b$ of Government Regulation Number 32 Year 1979 concerning Dismissal of Civil Servants (Dismissal of Civil Servants Regulation). Article 8 provides a bound discretion for government officials to dismiss civil servants not respectfully if they meet certain criteria.

The bound discretion embodied in the form of KTUN implies the existence of legal remedies by the aggrieved party. The aggrieved party may file a lawsuit to the Administrative Court. Permana research indicates that the lawsuit against the Decision of Regent of Klaten Number 888/01/12/09Rhs was won by the Defendant. Although the plaintiff is defeated, it shows that there is an opportunity for justice for the party who is harmed by the bound discretion of the KTUN.

Otherwise, discretion is not manifested in the form of a KTUN but a circular or instruction. Circular and instruction in various literatures of administrative law are classified as one form of policy rule, in addition to other forms such as operational guidelines and others. While on the other hand, the government has been showing the use of circular and instruction as an instrument of discretion. The intensity of circular use and instruction in government is quite a lot because of its simple formation procedure.

8 Permana, T.C.I. (2009). "Pengujian Keputusan Diskresi oleh Pengadilan Tata Usaha Negara." (Master Thesis). Post-graduate Diponegoro University, p. 87. 
The practice of circular use and instruction as a discretionary instrument can be seen from the intent and purpose of the issuance of the circular and the instruction. Some examples of circular use and instruction indicate that the purposes of circular and instruction are consistent with the purposes and objectives of discretion in the Government Administration Law, for instance:

Table 1. Government practices discretion by circular.

\begin{tabular}{|c|c|c|}
\hline No. & Circular & Substances \\
\hline & $\begin{array}{l}\text { Internal Affairs Circular } \\
\text { No. } 120 / 5935 / \text { SJ } 16^{\text {th }} \\
\text { October } 2015\end{array}$ & $\begin{array}{l}\text { The enactment of Law Number } 23 \text { Year } 2014 \text { on Regional } \\
\text { Government (Regional Government Law) resulted in the } \\
\text { change of several government affairs authorities at the } \\
\text { district/city and provincial levels. Changes in government } \\
\text { affairs also have implications on the status of personnel in the } \\
\text { region. Provisions in the Regional Government Law } \\
\text { governing the transfer of personnel shall be executed no later } \\
\text { than } 2 \text { (two) years from the enactment of the Law. Article } 21 \\
\text { of the Regional Government Law also delegates the formation } \\
\text { of Government Regulation as its implementing regulation. } \\
\text { However, the absence of such Government Regulation } \\
\text { resulted in legal vacuum and guidance for local government. } \\
\text { Therefore, the Minister of Infernal Affairs then issued this } \\
\text { Circular Letter as a guide in the transfer of government } \\
\text { affairs. If it refers to the discretion criteria in the Government } \\
\text { Administration Law, then the issuance of this Circular Letter } \\
\text { may be classified as discretion aimed at filling a legal vacuum } \\
\text { [Article } 22 \text { paragraph (2) Sub-Paragraph b of the Government } \\
\text { Administration Law]. }\end{array}$ \\
\hline
\end{tabular}

2. Internal Affairs Circular No. 471/1768/SJ 12 May 2016
Circular Letter addressed to regional heads throughout Indonesia related to the acceleration of issuance of electronic ID card and birth certificate. This Circular Letter adds a number of obligations that are not regulated in the Population Administration Law. For instance, residents who, on May 1, 2016, are more than 17 years old or are married and are not staying abroad, shall be required to record electronic ID card no later than September 30, 2016. The Population Administration Law does not stipulate the period of time for residents to perform data recording.

The circumstances underlying the issuance of this Circuli Letter are the coverage of electronic ID card recording whic only reaches $86 \%$ and the new Birth Certificate reaches $61.6 \%$. it refers to the discretion criteria in the Governmes Administration Law, the issuance of this Circular Letter may $\mathrm{k}$ classified as a discretion aimed at facilitating the administratic of government [Article 22 paragraph (2) a) of the Governme Administration Law]. 


\begin{tabular}{|c|c|c|}
\hline No. & Circular & Substances \\
\hline & $\begin{array}{l}\text { Director General of } \\
\text { Taxes No. SE- } \\
43 / \mathrm{PJ} / 2016\end{array}$ & $\begin{array}{l}\text { This Circular Letter is issued as a guidance on the } \\
\text { implementation and affirmation of the Regulation of the } \\
\text { Director General of Taxes no. PER-11/PJ/2016 concerning } \\
\text { Further Arrangement Concerning the Implementation of Law } \\
\text { Number } 11 \text { Year } 2016 \text { concerning Tax Amnesty. Specifically, } \\
\text { this Circular Letter is made so that tax amnesty services can } \\
\text { work well and uniform so as to provide legal certainty. As an } \\
\text { execution guide, this Circular Letter prevents different } \\
\text { interpretations in the implementation of the tax amnesty } \\
\text { program. If it refers to discretion criteria in the Government } \\
\text { Administration Law, then the issuance of this Circular Letter } \\
\text { may be classified as discretion aimed at providing legal } \\
\text { certainty [Article } 22 \text { paragraph (2) letter c of the Government } \\
\text { Administration Law]. }\end{array}$ \\
\hline
\end{tabular}

4. Presidential Instruction No. 1 of 2016 on Accelerated Implementation of National Strategic Projects
The Presidential Instruction (Inpres) was issued due to several national strategic projects whose progress was stagnant in the previous government period. The President wants to accelerate the implementation of these stagnant projects, especially on the National Strategic Project. Therefore, this Instruction gives some instructions to the Minister, Attorney General of the Republic of Indonesia, Chief of Police, Cabinet Secretary, Chief of Staff of the President, Heads of Non-Ministry Government Institutions, Governors and Regents/Mayors. The essence of some of these instructions is the need for relevant officials to take the necessary steps in resolving the obstacles to the implementation of the National Strategic Project. Even relevant officials are also instructed to take discretion in order to address concrete and urgent issues to avoid stagnation. If it refers to the discretion criteria in the Government Administration Law, the issuance of this Circular Letter may be classified as a discretion aimed at overcoming the stagnation of government in certain circumstances for the benefit and the public interest [Article 22 paragraph (2) Sub-Paragraph d of the Government Administration Law].

Source: Secondary data, 2017 (Edited).

Table 1 shows the form of discretion in the practice of government was not limited only in the form of KTUN. The practice of using circulars in discretion is a logical implication because the nature of the KTUN should be concrete, individual, and final. Whereas to fill the legal vacuum through discretion also required a legal product whose substance is regulatory and the substance of the arrangement (general-abstract) cannot be included in the KTUN. 


\section{Unconstitutionality of the Scope of Discretion in Government Administration Law}

Previous discussions have shown that the use of discretion in practice is not always consistent with those set forth in the Government Administration Law. The Government Administration Law regulates the use of discretion in the form of KTUN and factual actions (feitelijkehandelingen), but government practice shows the use of policy rules (especially in the form of circulars and instructions) as a discretionary instrument.

Problems can arise when the policy rule that becomes the discretion instrument is not in accordance with the requirements in Article 22 and Article 24 of the Government Administration Law:

a. According to the purpose of discretion, namely:

$i$. facilitate the implementation of government;

ii. fill the legal vacuum;

iii. provide legal certainty; and

iv. overcome the stagnation of government in certain circumstances for the benefit and the public interest.

b. Not contrary to the provisions of legislation.

c. In accordance with the General Principles of Good Administration (AUPB).

d. Based on objective reasons.

e. Not causing a conflict of interest.

f. Be done with good faith.

Discretionary constitutionality analysis will be based on Article 1 paragraph (3) of the 1945 Constitution of the Republic of Indonesia which states that Indonesia is based on rule of law. The focus of the discretionary constitutionality analysis is the synchronization between the rule of law in Article 1 Paragraph (3) of the Constitution with the scope of discretion in Article 1 Numbers 9 and Article 23 paragraph (1) of the Government Administration Law. Synchronization with the principle of the rule of law uses indicators of the rule of law that have been formulated by Adriaan Bedner. ${ }^{9}$ Bedner formulated 34 (thirty-four) indicators of the rule of law element. However, this discussion uses indicators relevant to the analysis of discretion. Therefore, the indicator proposed by Bedner was modified in order to be contextual with the use of discretion (see Table 2).

Discussion in this section, based on Bedner's formulation in Table 2 below, focused to examines whether the scope of discretion in Indonesian legal system is formally clear to give legal certainty. Furthermore, the discussion will examine the possibility of constitutional rights violation when the scope of discretion is limited in the Government Administration Law. Specifically, the discussion will analyze discretion in the form of policy rules which is not recognized in Government Administration Law. If the policy rules is not recognized in Government Administration Law but often used in practices, it may give consequences to the controlling mechanisms.

9 Bedner, A. (2010). "An Elementary Approach to the Rule of Law”. Hague Journal on the Rule of Law, 2(1): 48-74. DOI: https://doi.org/10.1017/S1876404510100037. 
Table 2 Dimensions and Indicators in the Constitutionality Analysis of the Scope of Discretion.

\begin{tabular}{lll}
\hline \multicolumn{1}{c}{ Elements } & \multicolumn{1}{c}{ Dimensions } & \multicolumn{1}{c}{ Indicators } \\
\hline Formal & Rule by law & $\begin{array}{l}\text { To what extent does the government operate by } \\
\text { discretion based on Government Administration }\end{array}$ \\
\cline { 2 - 3 } & State actions are subject to law & $\begin{array}{l}\text { To what extent does the law leave room for } \\
\text { discretionary powers'? }\end{array}$ \\
\cline { 2 - 3 } & Formal legality & $\begin{array}{l}\text { Whether the scope of discretion clears? } \\
\text { Whether all discretionary instruments } \\
\text { accessible to the public? } \\
\text { Whether all discretionary instruments } \\
\text { published? }\end{array}$ \\
\hline Substantive & $\begin{array}{l}\text { Subordination of all law and its } \\
\text { interpretations to fundamental } \\
\text { principles of justice }\end{array}$ & $\begin{array}{l}\text { What are the principles of justice and AUPB } \\
\text { that are written and enforceable? }\end{array}$ \\
& $\begin{array}{l}\text { Protection of individual rights and } \\
\text { group rights }\end{array}$ & $\begin{array}{l}\text { Whether individual and group rights } \\
\text { guaranteed? }\end{array}$ \\
\hline Controlling & There exists an independent judiciary & $\begin{array}{l}\text { Do citizens have effective access to justice in } \\
\text { controlling discretion? }\end{array}$ \\
\hline
\end{tabular}

Source: Bedner, 2010, p.72 (Edited).

For instance, the citizens do not have access to examine the policy rules in judicial system. If the scope of discretion in the Government Administration Law is not in accordance with the rule of law indicators, so it can affect to possibility of abuse of power by policy rules. The governments can use policy rules to violate the constitutional rights based on discretion and cannot be controlled by citizens.

\subsection{Formal Elements of Rule of Law}

Previous discussions have shown that government practice with discretion is not based on the scope of discretion specified by the Government Administration Law. Policy rules tend to be used as a discretionary instrument because of its easier and faster formation procedures. Moreover, not all discretionary contexts can be answered with the form of KTUN or factual actions as specified in the Government Administration Law.

The limits of the scope of discretion as prescribed by the Government Administration Law, only in the form of KTUN and factual acts, essentially deviate from the theoretical concepts of discretion that cannot be separated from policy rules. Policy rule is enacted due to government problems that cannot be solved if only based on laws. ${ }^{10}$ The context of the use of these policy rules is in accordance with the terms of use of discretion set out in the Government Administration Law.

The use of policy rules as a discretionary instrument is also often found in legal systems in other countries. The United States, for example, regulates policy rules with various variants of its form as a discretionary instrument. The policy rules in the United States are also governed by the Administrative Procedure Act. ${ }^{11}$

10 Manan, B., and Magnar, K. (1997). Beberapa Masalah Hukum Tata Negara Indonesia. Bandung: Alumni, p. 136.

11 Gersen, J.E. (2007). “Legislative Rules Revisited”. The University of Chicago Law Review, 74 (Special Issue: Commemorating Twenty-Five Years of Judge Richard A. Posner): 1709. 
The policy rules in the Netherlands (known as beleidsregel) are also regulated by the Law governing the public administration, namely Algemene Wet Bestuursrecht (AWB). Beleidsregels in the Netherlands is legally understood as a written decision whose substance is general but not universally binding and issued by the administrative body in the exercise of its authority with the aim of establishing certain facts or interpreting legislation. ${ }^{12}$ The context of beleidsregels in AWB is also a discretion context in Indonesia regulated by the Government Administration Law.

Comprehensive regulation of the form of policy rules - which tend to be the instrument of discretion - in the Government Administration Law can have implications on legal certainty. Legal certainty if reconstructed in the context of policy rules with reference to Maxeiner ${ }^{13}$ can be interpreted as follows:

a. Policy rules should be published as legislation enacted in the State Gazette. The publication shows that policy rules as outcome of discretion can be known to the affected public.

b. The policy rules should be clear so that they are not multiple interpretations. Clearly, in this criterion, is the precise formulation of norms so that it can be described and applied with certainty in the actions of legal subjects.

c. Policy rules should not be retroactive. The principle of non-retroactive in general is also adopted in the formulation of norms of legislation. The non-retroactive principle may be exempted from a policy rule if then its application is favorable to the legal subject.

d. The formation of a policy rule should pay attention to the principle of reasonable expectation (principle of trust), so that the policy rules issued by the government are required to be used by citizens to take action. ${ }^{14}$

Based on Maxeiner's arguments, if the Government Administration Law does not regulate the policy rules formally it may affect to administration practices which is not accordance with rule of principles in Article 1 paragraph (3) of the Indonesian Constitution:

a. The government does not have a guidance to make a policy rule based on procedures and good governance principles;

b. Because the government does not have guidance, the policy rules may not give legal certainty when the government uses discretion to solve a problem.

\subsection{Substantive Elements of Rule of Law}

Indicators in the substantive elements is relating to the applicable principles of justice and AUPB as well as guarantees of the human rights. The principle of justice and AUPB can be applied to the discretion in the form of KTUN because AUPB has become the valid criterion of KTUN since the coming into effect of the Administrative Court Law and reinforced by the Government Administration Law [Article 52 paragraph (2)].

12 Tollenaar, A. (2008). Gemeentelijk Beleid en Beleidsregels. Dissertation. Rijksuniversiteit Groningen.

13 Maxeiner, J. (2008). "Some Realism about Legal Certainty in the Globalization of the Rule of Law", Houston Journal of International Law, 31(1): 32.

14 Pratiwi, C.S., et.al. (2017). Penjelasan Hukum Asas-Asas Umum Pemerintahan yang Baik (AUPB). Jakarta: Lembaga Kajian \& Advokasi Independensi Peradilan (LeIP), p. 70. 
As in the formal element indicator of the rule of law, problems can arise if the discretion is made by the government in the form of a policy rule that is not legally regulated as a scope of discretion in the Government Administration Law. Violation of AUPB in the use of policy rule can be seen in polemic about the issuance of Circular Letter of Minister of Infernal Affairs, Number 700/08/SJ (SE No. 700/08/SJ) and Circular Letter of Minister of Infernal Affairs Number 555/3032/SJ (SE No. 555/3032/SJ).

The issuance of the two circulars was an implication of the enactment of Government Regulation Number 37 Year 2006 concerning Second Amendment of Government Regulation Number 44 Year 2004 regarding Protocol and Finance Position of Leaders and Members of Regional People's Representative Assembly (PP No. 37 Year 2006). PP No. 37 Year 2006 had raised Intensive Communication Allowance and Operational Support Cost of Regional People's Representative Assembly (DPRD) members throughout Indonesia. Increase in Intensive Communication Allowance and Operational Support Cost were retroactive.

The enactment of the allowances increase was criticized by the public. The Government then promulgated Government Regulation Number 21 of 2007 on Third Amendment of Government Regulation Number 44 of 2004 on Protocol and Financial Position of Leaders and Members of the Regional People's Representative Assembly (PP No. 21 Year 2007). PP No. 21 of 2007 requires members of the DPRD to refund allowance that has been received with a deadline of one month before the end of the term of office. The Minister of Infernal Affairs then issued Circular Letter no. 700/08/SJ dated 5 January 2009 which is intended for all DPRD members in Indonesia and requested members of the DPRD to refund the allowances that resulted from the enactment of PP No. 37 of 2006. However, the Minister of Infernal Affairs then issued Circular Letter no. 555/3032/SJ on August 18, 2009 which revoked the previous circular letter. Members of DPRD who do not refund the benefits will not be sanctioned.

The publication of the two circulars is a concrete example of the use of a circular as a form of discretion. Circular issuance is done without careful consideration and can even change quickly in a matter of months. If the circular is analyzed from the perspective of AUPB it would be contrary to several principles, including:

a. The principle of carefulness, that decision makers always act carefully by considering comprehensively about all aspects of decision material, so as not to cause harm to the citizens. ${ }^{15}$ The publication of the circular is also contrary to the principle of material precision. The principle of material precision in AWB in the Netherlands requires that the burden caused by the decision of government officials should not be more severe than the goal to be achieved. 16

b. The principle of legal certainty, that any decision made by the Government is not to be revoked, unless there are important matters which are the basis of recall and this must be proven through a valid judicial process. ${ }^{17}$

15 Nugraha. S. (2007). Laporan Akhir Tim Kompendium Bidang Hukum Pemerintahan yang Baik. Jakarta: BPHN, p. 12.

16 Pratiwi et.al, Op.cit, p. 66.

17 Ibid, p. 55. 
The use of a circular as a form of discretion, if it refers to the polemic of the circular letter, should be regulated in the Law so that its formal and material aspects are not contradictory to AUPB. The regulatory urgency is reinforced by empirical governance practices that use many circulars. If it is not regulated then the policy rule may be an instrument used arbitrarily in discretion.

\subsection{Controlling mechanisms}

This indicator requires citizens to have effective access to justice in exercising control over discretion. This indicator in the Indonesian context requires legal certainty that all forms of discretion can be controlled. The Government Administration Law regulates the control mechanisms against discretion, but limited to those that include the scope of discretion i.e. KTUN and factual action. Such control mechanisms include the notification and reporting mechanism of discretion to officials' superiors.

In addition to the control mechanisms of top officials, discretion can also be reviewed through administrative efforts (objection and appeal) and Administrative Court. The lawsuit against discretionary use through Administrative Court is possible because of the use of discretion in the forms of KTUN and the government's factual action.

Can citizens file a lawsuit through the Administrative Court on discretion in the form of a policy rule (circular or instruction)? If it refers to the scope of the lawsuit in the Administrative Court Law and synchronized with Article 87 of the Government Administration Law, then the policy rule cannot be the object of the lawsuit in the Administrative Court.

The judicial control effort that can be used by citizens against discretion is judicial review. Judicial review is done by applying to the Supreme Court. If tracing the Supreme Court decisions related to the circular judicial review, it can be concluded that there is no legal certainty for citizens in controlling through the judiciary against the discretion in the form of policy rules.

The Institute for Criminal Justice Reform (ICJR) has filed a petition for a judicial review of Supreme Court Circular Number 7 of 2014 on the Submission of a Request for Criminal Case Review (SEMA No. 7 of 2014). The Supreme Court through Judgment No. $27 \mathrm{P} / \mathrm{HUM} / 2015$ states the petition for judicial review is unacceptable. The Supreme Court declares that the petition for judicial review is unacceptable because the position of a circular is not a statutory regulation under Law Number 12 Year 2011 concerning the Establishment of Laws and Regulations.

However, the Supreme Court has a different opinion when conducting a judicial review against Letter of Director General of Islamic Education of the Ministry of Religious Affairs of the Republic of Indonesia No. DJ.I/PP.00.9/973/2009. Supreme Court, in Judgment No. 03 P/HUM/2010, granted part of the petition for judicial review. The Supreme Court in its legal consideration states that the format of the Director General Letter No. DJ.I/PP.00.9/973/2009 is like an ordinary letter, but the contents are provisions and generally applicable to all those referred to in the letter. So, the letter substantively meets the category of legislation and can therefore be submitted a petition for judicial review.

Supreme Court in Judgment No. 23 P/HUM/2009 also has a similar argument with Judgment No. 03 P/HUM/2010 when reviewed Letter of Director General of Coal and Geothermal Minerals of the Ministry of Energy and Mineral Resources No. 03/31/DJB/2009. Supreme Court argued that circular letter, based on practices of 
government administration, is a form of regulation and can be reviewed by Supreme Court.

Judgment No. 23 P/HUM/2009 and Judgment No. 03 P/HUM/2010 showed that the policy rules substantively have a similar impact with legislation and can be reviewed by Supreme Court. However, Judgment No. 27 P/HUM/2015 showed that judges in Supreme Court do not have a common view about judicial review of policy rules. The Supreme Court opinion in Judgment No. 27 P/HUM/2015 was based on the principle of legality which policy rules is not form of regulation that can be reviewed by Supreme Court. In the other hand, the Government Administration Law closed the possibility to review the policy rules in administrative court (PTUN) and furthermore creates the legal uncertainty condition in the perspective of controlling mechanism.

The legal uncertainty condition shows the weakness of control through judicial institutions against discretion in the form of policy rules. Control of discretion in the form of a policy rules can only be done by the superior officer who issued the policy rules. However, such control mechanisms are not regulated in legislation, so there is no obligation for officials to notify or report the use of policy rules as discretionary such as the use of discretion in the form of KTUN and factual action.

\section{Conclusion}

The analysis of the constitutionality of the scope of discretion in Article 23 paragraph (1) of the Government Administration Law indicates that the scope of discretion is contrary to the principle of the rule of law in Article 1 paragraph (3) of the Indonesian Constitution. Synchronization of indicators of rule of law - through the reconstruction of the concept of the rule of law by Bedner - with the scope of discretion in the Government Administration Law shows that the regulation of the scope of discretion in Article 23 paragraph (1) of the Government Administration Law has the potential to cause constitutional losses for the citizens. The potential constitutional losses are due to discretion limited in the form of KTUN and factual action and the practice of government showed that discretion is not limited to that forms. Practices in government indicate the usual use of circulars (as one form of policy rules) in discretion. The use of policy rules in discretion is an implication of legal vacuum that needs to be regulated through discretion in the form of regulatory legal products.

The discretion formed in the policy rules cannot be controlled by referring to the Government Administration Law. If the discretion in the form of a policy rules is contrary to legislation and/or AUPB, then the control can only be performed by the officer's supervisor. But the control is not mandatory because it is not regulated in legislation. In the other hand, citizens do not have access to discretionary controls in the form of policy rules through the judiciary.

Therefore, the following legal reforms are required:

a. The Government Administration Law should extend the scope of the discretion so it is not limited to KTUN and factual action by add policy rules as one of the scope of discretion and affirming nomenclatures which can be categorized as policy rules, such as circulars and instructions. 
b. The Supreme Court needs to amend the Supreme Court Regulation No. 1 of 2011 on Judicial Review. The changes are by expanding the scope of the object of the judicial review request. These changes have implications for controlling circulars that are regulatory, including those formed in the context of discretion, through the judiciary.

\section{References}

Bedner, A. (2010). "An Elementary Approach to the Rule of Law," Hague Journal on the Rule of Law, 2(1), 48-74. DOI: https:/ / doi.org/10.1017/S1876404510100037.

Darumurti, K.D. (2016). Diskresi: Kajian Teori Hukum. Yogyakarta: Genta Publishing.

Fletcher, G.P. (1984). “Some Unwise Reflections about Discretion," Law and Contemporary Problem", 47(4): 269-286.

Gersen, J.E. (2007). “Legislative Rules Revisited," The University of Chicago Law Review, 74, Special Issue: Commemorating Twenty-Five Years of Judge Richard A. Posner, 1705-1722.

Hart, H.L.A. (2013). “Discretion,” Harvard Law Review, 127(2): 652-665.

Li, L. (2014). Judicial Discretion within Adjudicative Committee Proceedings in China: A Bounded Rationality Analysis. Berlin: Springer-Verlag.

Manan, B., and Magnar, K. (1997). Beberapa Masalah Hukum Tata Negara Indonesia. Bandung: Alumni.

Maxeiner, J. (2008). "Some Realism about Legal Certainty in the Globalization of the Rule of Law," Houston Journal of International Law, 31(1), 27-46.

Nugraha, S. (2007). Laporan Akhir Tim Kompendium Bidang Hukum Pemerintahan yang Baik. Jakarta: BPHN.

Permana, T.C.I. (2009). "Pengujian Keputusan Diskresi oleh Pengadilan Tata Usaha Negara." (Master Thesis). Semarang: Post-graduate Diponegoro University.

Pratiwi, C.S., et.al. (2017). Penjelasan Hukum Asas-Asas Umum Pemerintahan yang Baik $(A U P B)$. Jakarta: Lembaga Kajian \& Advokasi Independensi Peradilan (LeIP).

Radbruch, G. (2006). "Statutory Lawlessness and Supra-Statutory Law (1946)," Oxford Journal of Legal Studies, 26(1), 1-11. DOI: http://dx.doi.org/10.1093/ojls/ gqi041.

Sitorus, L.E. (2016). "Kebijakan Bailout Century: Diskresi atau Kriminalisasi Kebijakan," Jurnal Hukum \& Pembangunan, 46(1): 22-49.

Tollenaar, A. (2008). Gemeentelijk Beleid en Beleidsregels. Dissertation. Rijksuniversiteit Groningen. 